a plant of a very different family, viz. Solanum rostratum (American Naturalist, April, 1882, p. 281): one stamen and the pistil are very long and strangely curved; four stamens are short and straight, and serve only to furnish pollen to the visiting insects ; all the anthers, as I am informed by Prof. Todd, are of the same dull yellow colour.

FRITZ MÜLLER

Blumenau, Santa Cattarina, Brazil, December 27, I882

\section{The Markings on Jupiter}

AFTER heavy storms of hail on January 30 , the sky clearer and the night was exceptionally fine. I observed Jupiter with my Io-inch reflector about IIh. $30 \mathrm{~m}$., and watched the chief markings pass the central meridian of the planet. The wellknown equatorial white spot came to transit at IIh. $44 \mathrm{~m}$., and it was followed 5 minutes later-at IIh. 490.-by the great red spot. These objects, therefore, must have been in conjunction on January 30 , at $2 \mathrm{~h} .47 \mathrm{~m}$., as the greater velocity of the white spot enables it to gain $13 \mathrm{~m}$. $24 \mathrm{~s}$. on the red spot daily.

In NATURE, vol, xxv. p. 225, I stated that during the $400 d$ oh. 20m. elapsed between 1880, November 19, 9h. 23m. and I88I, December $24,9 \mathrm{~h} .43 \mathrm{~m}$., the white spot had completed 9 revolution; of Jupiter relatively to the red spot ; the number of rotations performed by the former being 976 , and by the latter 967. Since 188 I, December 24, I have continued to watch the anomalous velocity of these curious markings, and find that between that date and 1883 , January 30 , the white spot has completed 9 further revolutions of Jupiter. From 1881, December 24 , $9 \mathrm{~h} .43 \mathrm{~m}$., to 1883 , January 30 , $2 \mathrm{~h} .47 \mathrm{~m}$., is $40 \mathrm{Id}$. $17 \mathrm{~h} .4 \mathrm{~m}$., during which the white spot has rotated 980 times, while the number for the red spot is $97 \mathrm{I}$. In fact my observations since 1880 , November 19 , show that up to 1883 , January 30 , the white spot had performed 1956 rotations, as against 1938 by the red spot in the interval of 8ord. I 7 h. $24 \mathrm{~m}$.

On January 30, when I last saw these markings, the red spot was remarkable on acc unt of it; great faintness. On the other hand, the equatorial white spot was extremely brilliant and conspicaous, and formed one of the most noticeable features on the planet. Observers should now keep a close watch on the red spot, as it seems likely to be on the point of disappearance, though this disappearance need not necessarily be of final character. It fortunately happens that a curious irregularity in the formation of the great southern belt will probably enable the exact position of the spot to be watched for a considerable time. This particular region of the planet, as I drew it on January 30 at midnight, was as follows :-

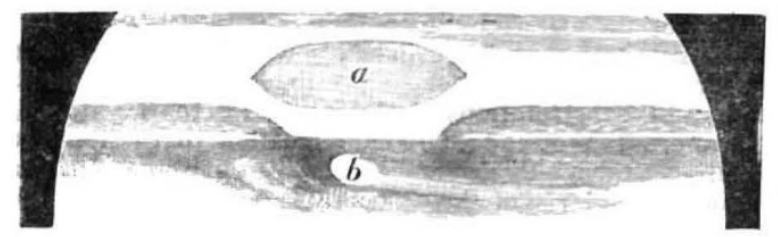

ז883, January $30, \mathrm{x} 2 \mathrm{~h}$. The region south of the equator of Jupiter. $a$, The red spot; $b$, white spot.

The sketch shows that the great south belt is now double, and a very conspicuous object on Jupiter. The south half of this belt is bent abruptly to north, and run; into the other half exactly north of the preceding and following ends of the red spot. There is some explanation to this interesting feature, though it is at present involved in mystery; in any case it may possibly serve as a very accurate indication of the place of the red spot long after that object has become obliterated altogether.

Bristol, January 3 I

\section{Meteor of November I7}

I THINK now that more observations of the remarkable phenomenon of November 17 have been brought forward, that we cannot but candidly acknowledge that the evidence is extremely contradictory and impossible to reconcile, that is as applying to one and the same object. Altogether there is something mysterious about it. It is evident that since it appeared to reach the greatest apparent length of about $30^{\circ}$ at York, then from all places further south it ought to have attained a length exceeding this, the more so the further south they are. The ends of the beam appeared very well defined from here, and there was very little room for estimates varying according to the observer's sensitiveness to light. If we take the observations made from Clifton, Cirencester, East Clevedon, Woodbridge, and Windsor, as they nearly all agree in estimating the length as over $30^{\circ}$, some considerably over, then these may all relate to the same object. But its appearance from York is flatly contradicted by Mr. Batson's observation from Hungerford, that from Halstead, Essex (which seem; to agree with Mr. Batson's), also those from Lincoln's Inn Fields, Greenwich, and Cambridge. All these agree in contradicting the others named above, by assigning a much smaller angular length. Mr. Batson describes a sudden foreshortening which the meteoroid underwent when passing the moon, and since I saw it pass below the moon at practically the same time, then (on the supposition that we beheld the same object) the same shortening ought to have been visible to me; but there was not the slightest trace of any such thing. I noticed that it very gradually shortened in length (after allowing for perspective) in its journey towards the west, which is significant, and explainable if we suppose the body to have been encountering resistance to its momentum. It is im. possible to reconcile all the observations, and yet most extra. ordinary that no single observer is known to have witnessed more than one such phenomenon at about that time except $\mathrm{Mr}$. Worthington, who says he saw two at once. I have reason to helieve that a rather similar thing was seen below the moon at about 5.30 on that night from here. I see that from Ziericksee, in Holland, a similar phenomenon was seen to transit a Pegasi (which would be at about $50^{\circ}$ altitude, and on the magnetic meridian from there). If this was the one that I saw, then at the time that it was seen to transit a Pegasi, from Holland, it would appear to me to be just forming in the south-east, where it appeared to be about $10^{\circ}$ above the horizon, it which case it would have to be under seventy miles high when over Belgium. But it is alm sst certain that it attained a height of over 150 miles during the latter part of its course. As yet (firurarively speaking) the spectra of these auroral phen mmena have not thrown as much light on these things as that which enters the narrow slip of the spectroscope to print its uncertain record on the retina. I only hope that some one with a clear head and much patience will suc seed in unravelling the tangled skeins of evidence which surround the mysterious meteoroid of November 17, 1882 .

Heworth Green, York, February i I

\section{Aino Ethnology}

IN an article on "Ains Ethnology" which appeared in NATURE, vol. xxvi, p. 524, and which I happened to read only a few days ago, Mr. A. I1. Keane makes the following state ment :- "Until the appearance of Herr Rein's large work on Japan, one of the most universally-accepted of the se conclusions was that, whatever be their affinitie; the Ainos must certainly be separated from the Mong slic connection. No little surprise was accordingly produced by Rein's attempt to affiliate them to the surrounding members of the yellow race. But it was soon seen that his argument, a pparently inspired by a love of paradox, were sufficiently refuted by the very illustrations of the Aino type introduced into his work."

I submit that one who has read my work upon Japan will decide, with me, that the spirit of the matter quoted is unfair, in so far as it charges me with "attempts" at affiliation, and with being "inspired". o:herwise than by a love of truth-this motive being, as stated in my preface, that which induced me to write.

It is repeatedly mentioned in my book that I had never been in the island of Yezo, and those who have carefully read the whole work-including Mr. Keane, if he has done so-cannot reasonably fail to observe that I speak of the Aino tribe as one who had never visited them in their prozer home, nor made them a special subject of study in any respect. My remarks upon their probable racial affinities were based upon good, and the then latest, authorities, whose names I was careful to mention. Thus, on p. 444 , occurs a passage of which the following is a rendering:- "D senitz and Hilgendorf have made thorough investigations of their (the Ainos) physical peculiarities, and have pnblished the results thereof in the Miltheilungen der Deutschen Gesellschaft Ostasiens. It appeared as an undoubted fact 'that the Ainos are Mongolians, who are separated from the Japanese
in a perhaps less degree than the Germans from the Romans." 